\title{
Pharmacognostic, Antimicrobial and Toxicological Studies of a Seasonal Medicinal Plant; Tagetes Patula L
}

\author{
Tayyaba Mumtaz',*, Ghazala H Rizwani ${ }^{2}$, Bushra Hina ${ }^{3}$, Huma Sharif \\ ${ }^{1}$ Department of Pharmacognosy, Faculty of Pharmacy, Ziauddin University. \\ ${ }^{2}$ Department of Research, Hamdard University. \\ ${ }^{3}$ Department of Pharmacognosy, Institute of Pharmaceutical Sciences, Jinnah Sindh Medical University.
}

\begin{abstract}
Authors' Contributions
1 Conception \& Study Design, Data Collection \& Processing, Data Analysis and/or Interpretation, Drafting of Manuscript.

2 Conception \& Study Design, Drafting of Manuscript, Critical Review.

3 Drafting of Manuscript, Critical Review.

4 Data Analysis and/or Interpretation, Critical

Review.
\end{abstract}

\section{Acknowledgement}

\section{Article info.}

Received: January 12, 2020

Accepted: February 24, 2021

Funding Source: Nil

Conflict of Interest: Nil

Cite this article: Mumtaz T, Rizwani GH, Hina $B$, Sharif H. Pharmacognostic, Antimicrobial and Toxicological Studies of a Seasonal Medicinal Plant; Tagetes Patula L. RADS J Pharm Pharm Sci. 2020; 8(4):242-247.

*Address of Correspondence Author: tayyaba.faraz@zu.edu.pk

\section{A B S TRACT}

Purpose of this study: This study has been carried out to explore the medicinal significance of Tagetes patula by evaluating its in vitro antibacterial, antifungal and toxicological effects. Pharmacognostic standardization is done to maintain the purity and quality of the drug.

Methodology: Pharmacognostic studies (macro morphology and microscopy i.e. Histology and powder microscopy), solubility and color reaction of T.patula were carried out followed by in vitro antimicrobial studies of ethanol extract of the flowers. In this regard antibacterial, antifungal, and toxicological studies were performed by well diffusion, Agar dilution, and larvicidal activity respectively.

Results: Flower extract of $T$. patula showed good antibacterial effects against gram +ve and gram -ve bacteria except Shigella flexanri. Moreover it showed powerful antifungal effects against various human (Aspergillus flavus, Candida glabrata, Trichophytonlongifusus), plant (Fusariumsolani)and animal pathogens (Microsporumcanis). Moreover remarkable larvicidal activity was observed against brine shrimp at 100 and $1000 \mu \mathrm{g} / \mathrm{ml}$.

Conclusion: This research study makes the valuable medicinal plant a good candidate for skin infections and wound management for topical use.Such studies will help in formulating topical herbal preparations to combat inflammatory and infectious skin disease.

Keywords: Tagetespatula, Pharmacognostic standardization, antimicrobial, Shigella flexanri,. Trichophyton longifusus ,Fusarium solani,brine shrimp.

\section{INTRODUCTION}

Plant derived products serves as potential source of modern drugs. In developed countries $13 \%$ of medicine consumed are based on herbs However, only fewer plants i.e. 15\% were undergone proper investigation. According to report generated by World Health Organizations herbal medicines are easier to access, effective, nontoxic, relatively cheap and have lesser side effects[1]. Natural plant products offered great treasure of secondary metabolites which have been displayed enormous biological and pharmacological activities [2]

The ornamental plant Tagetespatula (Asteraceae) is well known for its reddish yellow, orange colored beautiful flowers [3]. Name of plant is common as French marigold and Genda[4]. Tagetespatula is rich in commercially important carotene compounds, helenien, xanthophyll, essential oil ,thiophene, steroids and terpenoids [5, 6].The plant can be used 
in the form of extracts, powder, decoction, juices, infusions and oils for the treatment of various diseases.i.e juice of flowers are used in this remedy given to a patient produces strengthening of connective tissues, enhance healing process and decreases inflammation and act as analgesic. Crushed flowers are used as remedy to purify blood in 15 days. Traditionally flowers heads are used to kill internal worms and proved as anthelmintic. Commercially flower oil can be used as insect repellent and modifier in hair lotions also the oil has been used as food additive and food colorants(4). oil also acts as antiseptic as well as antifungal in candidiasis and other infections whereas roots and seeds are employed as purgative. Aqueous extract of the flower showed antibacterial while methanolic extract possessed anti inflammatory activity [5].

\section{MATERIALS AND METHODS}

\section{Plant Material}

The fresh flowers of T.patula $(2 \mathrm{~kg})$ were purchased from local nursery of Karachi, in November 2016 and identified by Prof. Dr. Surraya Khatoon, Department of Botany, Faculty of Science, University of Karachi voucher specimen number (0043) were deposited in herbal museum of Department of Pharmacognosy , University of Karachi.

\section{Preparation of Extracts}

Fresh flowers of Tagetes patula were first clean and after that ray and disc florets were removed and percolated in ethanol at room temperature for 10-15 days. After that percolate was filtered by whattman filter paper no 1 and dried in rotary evaporator at 39$40 \stackrel{\circ}{ } \mathrm{C}$ under reduced pressure. This procedure was repeated thrice. Obtained semisolid ethanolic extract was lyophilized on freeze drying apparatus under reduce pressure, to get powder brown extract (24gm).

\section{Histological Evaluation}

The transverse section of the florets of T.patula were examined through cellular sequences by making permanent slides. Method was adopted by staining and glutening. After that complete histology was studied by means of electronic microscope. $[7,8]$.

\section{Microscopic Examination}

Flower were first clean to remove dirt and unwanted debris and then dried under shade thereafter dried powder material evenly ground and analyzed for powder microscopy. The powdered material treated one by one with glycerin (50\%), iodine solution $(5 \%)$ and chloralhydrate solution (10\%) [7,9].

\section{Solubility and Reaction of Powder Drug with Various Reagents}

Tagetes patula showed different solubility patterns and changes of colour when mix up in various chemical agents [10].

\section{Antimicrobial Activity}

Microorganisms were obtained in this research work from HEJ, research Institute of Chemistry, University of Karachi.a-Gram-Positive Bacteria: Staphylococcus aureus, Bacillus subtilis. b-Gram-Negative Bacteria: Escherichia coli, Salmonella typhi, Shigella flexenari,Pseudomonas aeruginosa. Three types of fungal organism were used in the study i) Plant Pathogens: Fusariumsolani, ii) Animal Pathogens: Microsporum canis, and iii) Human Pathogens: Aspergillus flavus,Candida albicans, Trichophyton longifusus, Candidaglabrata.

\section{Antibacterial Activity}

The antibacterial activity was evaluated by Well diffusion method. Amoxicillin was used as standard drug and as medium, nutrient agar was employed. Inoculation of nutrient plates were done within $24 \mathrm{hrs}$. Old bacterial cultures around $10^{8}-10^{-6} \mathrm{CFU} / \mathrm{ml}$ were taken. Wells with size of $8 \mathrm{~mm}$ were made in the nutrient media. Reference drug along with samples were incorporated into the media with concentration of $100 \mathrm{mg} / \mathrm{ml}$. DMSO was used as negative control. The inhibitory zone of Gram+ve and Gram-ve organisms were noted and then compared with standard.[11].

\section{Antifungal Activity}

The method used to screen antifungal activity of crude extract of Tagetes patula was Agar dilution. Miconazole, and Amphotericin B were used as reference drug. Sabouraud dextrose agar (SDA) subjected to maintain fungal organism growth. The broth was kept in incubator for $24 \mathrm{hrs}$. at $37^{\circ} \mathrm{C}$. A dilution of 1:100 in distilled water was used in the test. The petri plates prepared with SDA. In the media wells $(6 \mathrm{~mm})$ were dug for test and standard samples each having concentration $(100 \mathrm{mg} / \mathrm{ml})$ respectively. While for negative control DMSO was used. The plates were remains in incubator for $24 \mathrm{hrs}$. at $37^{\circ} \mathrm{C}$. [12] Results were noted by measuring zone of inhibition in $\mathrm{mm}$ and then compared with standard. 
The obtained mean values were calculated as follows:

100-Linear growth in test $(\mathrm{mm}) /$ Linear growth in control $(\mathrm{mm}) \times 100$.

\section{Larvicidal Activity}

The toxic manifestations of bioactive compounds depicted some information about high or low level of toxicities by Brine shrimp bioassay method which is a rapid and preliminary method. The brine shrimps eggs were conveniently hatched in the artificial sea water at $25 \mathrm{C}$ in $24 \mathrm{hrs}$. This was prepared with $3.8 \mathrm{~g}$ sea salt in $1000 \mathrm{ml}$ of distilled water and thereafter filtered. By this method large number of larvae have been produced. Ethanolic extract in concentration of 10,100 and $1000 \mu \mathrm{g} / \mathrm{ml}$ with $5 \mathrm{ml}$ of sea water and ten shrimps in each vial were kept in incubator for $24 \mathrm{hrs}$. at $27{ }^{\circ} \mathrm{C}$. The numbers of shrimps survived was counted after $24 \mathrm{hrs}$. In this protocol, the negative control was served as solvent. While the standard drug Ectoposide with $\mathrm{LD} 50=7.465 \mu \mathrm{g} / \mathrm{ml}$ was used as positive control. [13].

\section{RESULTS}

Cellularprofile of crude drug was examined on the basis of microscopic techniques shown in [Figure.1]. The diagnostic characters of $T$. patula flower in various detecting reagent are summarized in [Figure. 2]. The overall solubility pattern of crude disc and ray florets in various polar and non polar solvents are observed in Table 1.

Results of antibacterial and antifungal activity against various pathogens are shown in (Table 2 and 3 ) respectively. Flower extract of $T$. patula showed good antibacterial effects against gram +ve and gram -ve bacteria except Shigella flexanri. Moreover it showed powerful antifungal effects against various human (Aspergillus flavus, Candida glabrata, Trichophyton longifusus), plant (Fusariumsolani)and animal pathogens (Microsporumcanis). At various concentrations the extract behaves different larvicidal activity which is depicted in Table 4.

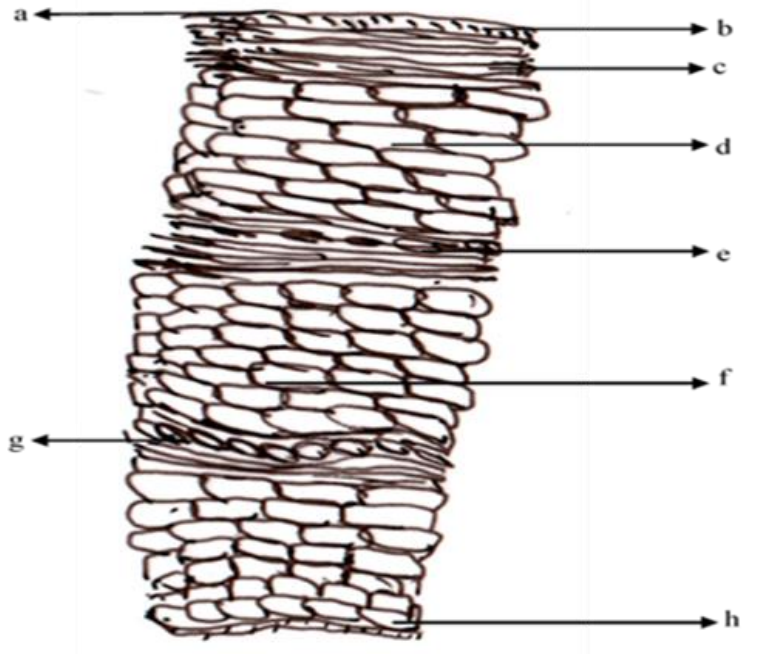

Figure 1. Transverse Section of of Tagetes patula.

a) Cuticle b) Upper Epidermis c) Upper zone endodermis with thin layered cells d) Hypodermal cells e) Middle zone of endodermis with lignified cells f) Mesodermal cells g) Lower zone of endodermis $h$ ) Lower epidermis.

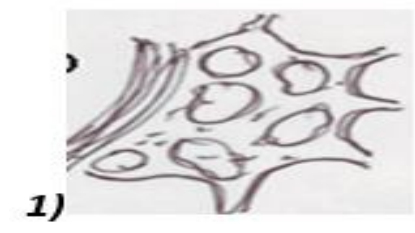

(2)
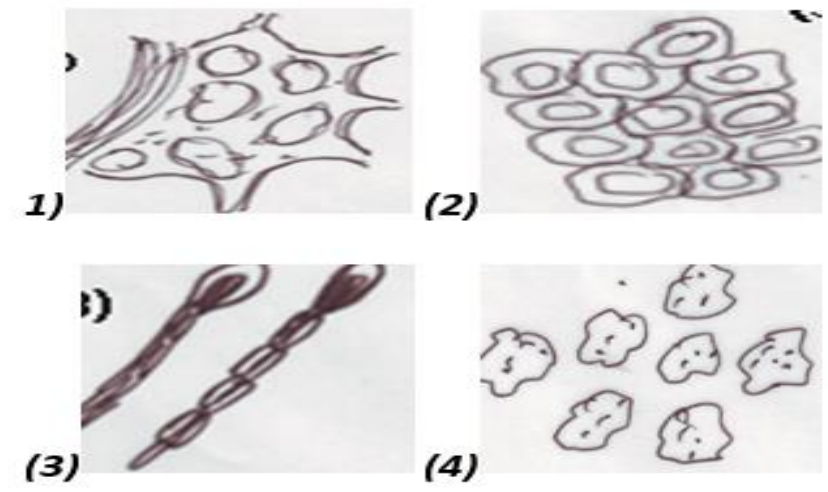

(5)
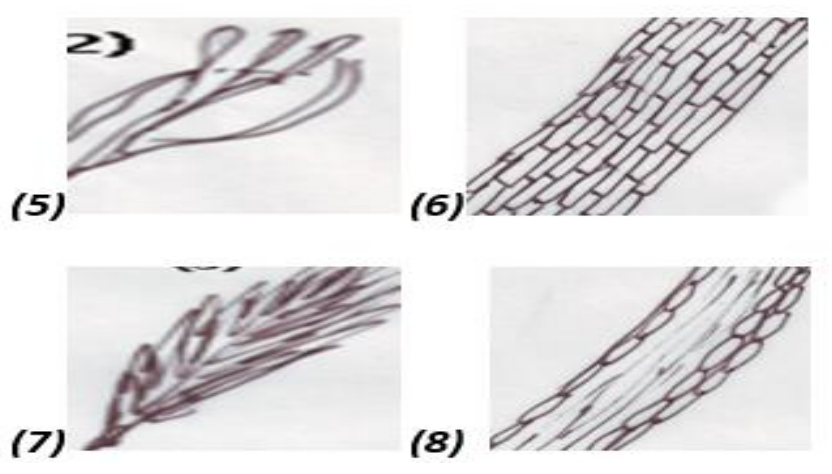

Figure 2. Microscopic examination of T.patula florets in chloral hydrate, glycerin and iodine solution.

1) Parenchyma of hypanthium showing an oil gland

2) Sheet of collenchyma 3) glandular trichome 4) Immature pollen grains 5) Fibers 6) An overview of rectangular cells of epidermis 7 ) More spiny trichome 8) Segmented epidermis with fibers. 
Table 1. Color Reactions and Solubility Changes of Tagetes Patula.

\begin{tabular}{|c|c|c|c|c|c|c|}
\hline Chemicals & $\begin{array}{c}\text { Solubility } \\
\text { (Ray } \\
\text { florets) }\end{array}$ & $\begin{array}{c}\text { Actual } \\
\text { Color of } \\
\text { Ray } \\
\text { florets }\end{array}$ & $\begin{array}{l}\text { Color } \\
\text { Change }\end{array}$ & $\begin{array}{l}\text { Solubility } \\
\text { (Disc florets) }\end{array}$ & $\begin{array}{l}\text { Actual Color } \\
\text { of Disc florets }\end{array}$ & Color Change \\
\hline $\begin{array}{l}\text { Powder+ } \\
\text { H2SO4 }\end{array}$ & $\begin{array}{l}\text { On heating } \\
\text { soluble }\end{array}$ & $\begin{array}{l}\text { Reddish } \\
\text { Brown }\end{array}$ & $\begin{array}{l}\text { Black } \\
\text { solution }\end{array}$ & $\begin{array}{l}\text { On heating } \\
\text { soluble }\end{array}$ & $\begin{array}{l}\text { Reddish } \\
\text { Orange }\end{array}$ & Black solution \\
\hline $\begin{array}{l}\text { Powder+ } \\
\mathrm{CH} 3 \mathrm{COOH}\end{array}$ & $\begin{array}{l}\text { On heating } \\
\text { Slightly } \\
\text { soluble }\end{array}$ & $\begin{array}{l}\text { Reddish } \\
\text { Brown }\end{array}$ & $\begin{array}{l}\text { Yellowish } \\
\text { Orange }\end{array}$ & $\begin{array}{l}\text { On heating } \\
\text { insoluble }\end{array}$ & $\begin{array}{l}\text { Reddish } \\
\text { Orange }\end{array}$ & $\begin{array}{l}\text { Yellowish } \\
\text { Orange }\end{array}$ \\
\hline $\begin{array}{l}\text { Powder+ } \\
\text { Benzene }\end{array}$ & $\begin{array}{l}\text { On heating } \\
\text { insoluble }\end{array}$ & $\begin{array}{c}\text { Reddish } \\
\text { Brown }\end{array}$ & $\begin{array}{l}\text { No change } \\
\text { of color }\end{array}$ & $\begin{array}{l}\text { On heating } \\
\text { insoluble }\end{array}$ & $\begin{array}{l}\text { Reddish } \\
\text { Orange }\end{array}$ & $\begin{array}{l}\text { No color } \\
\text { change }\end{array}$ \\
\hline $\begin{array}{l}\text { Powder+ } \\
\text { Methanol }\end{array}$ & $\begin{array}{l}\text { On heating } \\
\text { Slightly } \\
\text { soluble }\end{array}$ & $\begin{array}{l}\text { Slightly } \\
\text { soluble }\end{array}$ & $\begin{array}{l}\text { No change } \\
\text { of color }\end{array}$ & $\begin{array}{l}\text { on heating } \\
\text { soluble }\end{array}$ & $\begin{array}{l}\text { Reddish } \\
\text { Orange }\end{array}$ & $\begin{array}{l}\text { No color } \\
\text { change }\end{array}$ \\
\hline $\begin{array}{l}\text { Powder+ } \\
\text { water }\end{array}$ & $\begin{array}{l}\text { On heating } \\
\text { Slightly } \\
\text { soluble }\end{array}$ & $\begin{array}{l}\text { Reddish } \\
\text { Brown }\end{array}$ & $\begin{array}{l}\text { Light } \\
\text { Brown }\end{array}$ & $\begin{array}{l}\text { On heating } \\
\text { Slightly soluble }\end{array}$ & $\begin{array}{l}\text { Reddish } \\
\text { Orange }\end{array}$ & Light Brown \\
\hline
\end{tabular}

Table 2. Antibacterial Activity of Tagetes Patula.

\begin{tabular}{|c|c|c|c|}
\hline \multirow{2}{*}{ Group of Organisms } & Bacterial Cultures & $\begin{array}{c}\text { Zone of Inhibition of } \\
\text { Sample (mm) }\end{array}$ & $\begin{array}{c}\text { Zone of Inhibition } \\
\text { of Amoxicillin (mm) }\end{array}$ \\
\hline \multirow{2}{*}{ Gram +ve } & Staphylococcus aureus & 12 & 30 \\
\cline { 2 - 4 } & Bacillus subtilus & 20 & 35 \\
\hline \multirow{3}{*}{ Gram -ve } & Escheria coli & 17 & 35 \\
\cline { 2 - 4 } & Salmonella typhi & 16 & 30 \\
\cline { 2 - 4 } & Pseudomonas aeruginosa & 17 & 21 \\
\cline { 2 - 4 } & Shigellaflexanri & - & 40 \\
\hline
\end{tabular}

Table 3. Antifungal Profile of $T$. Patula.

\begin{tabular}{|c|c|c|c|c|c|}
\hline \multirow{2}{*}{$\begin{array}{c}\text { Class of } \\
\text { Pathogen }\end{array}$} & Name of Fungus & \multicolumn{2}{|c|}{ Linear Growth } & \multirow{2}{*}{$\begin{array}{c}\text { \%age of } \\
\text { Inhibition }\end{array}$} & \multirow{2}{*}{ Std Drug } \\
\cline { 3 - 5 } & Sample & Control & & \\
\hline \multirow{3}{*}{ Human } & Trichophyton longifusus & 30 & 100 & $70 \%$ & Miconazole \\
\cline { 2 - 5 } & Candida albicans & 70 & 100 & $30 \%$ & Miconazole \\
\cline { 2 - 5 } & Aspergillus flavus & 40 & 100 & $60 \%$ & Amphotericin B \\
\cline { 2 - 5 } & Candida glabrata & 40 & 100 & $60 \%$ & Miconazole \\
\hline Plant & Fusarium solani & 30 & 100 & $70 \%$ & Miconazole \\
\hline Animal & Microsporum canis & 30 & 100 & $70 \%$ & Miconazole \\
\hline
\end{tabular}

Table 4. Screening of Larvicidal Activities (Against Brine Shrimps) of Tagetespatula.

\begin{tabular}{|c|c|c|c|}
\hline \multirow{2}{*}{$\begin{array}{c}\text { Concentration of Solution } \\
(\boldsymbol{\mu} \mathbf{g} / \mathbf{m l})\end{array}$} & \multicolumn{3}{|c|}{ Tagetespatula (crude) } \\
\cline { 2 - 4 } & No. of survivors & No. of dead & \%age of Death \\
\hline Control & 10 & 0 & - \\
\hline 10 & 7 & 3 & $90 \%$ \\
\hline 100 & 1 & 9 & $100 \%$ \\
\hline 1000 & 0 & 10 & \\
\hline
\end{tabular}




\section{DISCUSSION}

In best of our knowledge powder microscopy and histological studies of T.patula florets was first time conducted in this studies. Histological evaluation revealed that epidermis consist of cuticle and single layered barrel shaped cells. On lower side small cystolyth were present. Upper zone consists of thin walled endodermis. While Middle zone composed of lignified cells but various oil cells abundantly found in lower zone. Parenchyma was wavy with numerous pigments. Both upper and lower layer covered with glandular trichomes. Various oil glands seen in transverse section [Figure.1]. In powder florets regular bands of red coloring globules were observed. Glandular trichomes were multicellular, unbranched, uniseriate i.e. globular, ovoid head was present with multicellular stalk. Group of oil glands seen in parenchyma of hypanthum. Hair like fibers were abundantly seen. Spherical, spiny pollen grains were present. Rectangular segmented thin layer epidermis was noticed, air spaces were tiny or absent. [Figure. 2]. In solubility testing both ray and disc florets showed polar characteristics i.e ray florets were soluble in sulphuric acid but slightly soluble in acetic acid, methanol and water while in Benzene they were insoluble. Whereas disc florets were insoluble in acetic acid and Benzene while soluble in water methanol and sulphuric acid. (Table 1) Ethanolic extract showed good activity against gram positive bacteria i.e. S. aureus and $B$. subtilus with respective zone of inhibition $12 \mathrm{~mm}$ and $20 \mathrm{~mm}$. The flower extract was also effective against $90 \%$ gram negative bacteria (E. coli, S. typhi, $P$. aeruginosa,) with respective zone of inhibition $17 \mathrm{~mm}, 16 \mathrm{~mm}$, and $17 \mathrm{~mm}$.when compared with standard drug Amoxicillin .It was interesting to note that in our study T.patula extract showed same strong inhibition against E.coli which is in agreement with previous research study [14] No zone of inhibition was shown in case of $S$. flexanri. Generally gram negative bacteria shown less susceptibility towards plant extracts as compare to gram positive bacteria due to the fact that their outer wall is composed of lipopolysaccharides and lipoprotein which behaves resistant for antibacterial entry (Table 2). [15]. The ethanolic extract has prominent antifungal activity against human pathogen i.e A. flavus, C. glabrata and especially $T$. longifusus, with $60 \%$ and $70 \%$ inhibition respectively. Fungal pathogen produces severe problems around world causing a number of human, plant and animal diseases. Like pathogenic $A$. flavus which is a real cause of aflatoxins can contaminate food commodities. T. longifusus (dermatophyte) responsible for hair, nail and scalp. infections [16] profound activity was also shown in case of F.solani $(70 \%)$ and $M$. canis $(70 \%)$. While least antifungal activity was demonstrated in case of C.albicans (Table 3). Similar outcomes have been reported by other studies which further proved the antimicrobial potentials of this plant $[2,17,18,19$,$] .The floral extract$ exhibited remarkable larvicidal activity, it was observed at concentration of 10 and $100 \mu \mathrm{g} / \mathrm{ml}$ the mortality rate was found to be $30 \%$ and $90 \%$ respectively and when the dose was increased up to $1000 \mu \mathrm{g} / \mathrm{ml}$ the rate of death was $100 \%$. Therefore, it is evident that when dose is increased the extracts works effectively. (Table 4) The strong cytotoxic activity (LC50 $5.58 \mu \mathrm{g} / \mathrm{ml}$ ) was also confirmed in methanolic leaves extract of same plant by Rahul khudus et al [2].

\section{CONCLUSION}

On the basis of this current study it can be concluded that Tagetes species showed good antibacterial and antifungal activities and might be used as a good candidate in healing wounds and other certain kind of skin infectious conditions. Moreover Pharmacognostic standardization has also performed that is necessary for quality control and authentication of the medicinal plant.

\section{REFERENCES}

1. Majumder S, Elango EM, Hoebe CJ, Rahmatullah M. Antibacterial studies with methanol and ethanol extracts of Tagetes patula flowers against methicillin-resistant Staphylococcus aureus. World Journal of Pharmacy and Pharmaceutical Sciences. $2014 ; 3(9): 682-91$.

2. Kuddus MR, Alam MS, Chowdhury SR, Rumi F, Sikder MA, Rashid MA. Evaluation of membrane stabilizing activity, total phenolic content, brine shrimp lethality bioassay, thrombolytic and antimicrobial activities of Tagetes patula L. J Pharmacog Phyto. 2012 ;1:57-62.

3. Rondon MA, Velasco J, Hernandez JO, Pecheneda M, Rojas JA, Morales AN, Carmona J, Diaz TU. Chemical composition and antibacterial activity of the essential oil of Tagetes patula L.(Asteraceae) collected from the Venezuela 
Andes. Revista Latino americana de Química. 2006;34(1/3):32.

4. Ramya R, Mahna S, Bhanumathi SP, Bhat SK. Analysis of phytochemical composition and bacteriostatic activity of Tagetes sp. Inter. Res. J. Pharm. 2012;3(11):114-6.

5. Jain R, Katare N, Kumar V, Samanta AK, Goswami S, Shrotri CK. In vitro antibacterial potential of different extracts of Tagetes erecta and Tagetes patula. J. Nat. Sci. Res. 2012;2: 84-90.

6. Narayan GR, Viswas K, Pathak M, Singh PS, Gupta A. Antibacterial activities of ethanolic extracts of plants used in folk medicine. International Journal of Research in Ayurveda and Pharmacy (IJRAP). 2010;1(2):529-35.

7. Tabasum S, Khare S, Jain K. MACROSCOPIC AND MICROSCOPIC EVALUATION OF ABRUS PRECATORIUS L.(GUNJA), SEEDS. INTERNATIONAL JOURNAL OF PHARMACEUTICAL SCIENCES AND RESEARCH. $2017: 1 ; 8(6): 2631-5$.

8. Kumar D, Buge PV, Bhat ZA, Dhumal JS. Macroscopical and microscopical evaluation of leaves of Clerodendrum inerme Gaertn. Int J Biol Med Res. $2011 ; 2(1): 404-8$.

9. Prabhu K, Karar PK, Hemalatha S, Mankar P. Morphological, Microscopical and Physicochemical Investigations on the roots of Viburnum punctatum Buch.-Ham. ex D. Don. Der Pharmacia Sinica (PelagiaResearchLibrary) 2011, 2 (2): 131. 2011;141.

10. Sultana S, Khan MA, Ahmad M, Bano A, Zafar M, Shinwari ZK. Authentication of herbal medicine neem (Azadirachta indica A. Juss.) by using taxonomic and pharmacognostic techniques. Pakistan Journal of Botany. $2011 ; 43: 141-50$.

11. Sen A, Batra A. Evaluation of antimicrobial activity of different solvent extracts of medicinal plant: Melia azedarach L. Int J Curr Pharm Res. 2012 4, (2):67-73.

12. Bhalodia NR, Shukla VJ. Antibacterial and antifungal activities from leaf extracts of Cassia fistula I.: An ethnomedicinal plant. Journal of advanced pharmaceutical technology and research. $2011 ; 2(2): 104$.
13. Bastos ML, Lima MR, Conserva LM, Andrade VS, Rocha EM, Lemos RP. Studies on the antimicrobial activity and brine shrimp toxicity of Zeyheria tuberculosa (Vell.) Bur.(Bignoniaceae) extracts and their main constituents. Annals of Clinical Microbiology and Antimicrobials. 2009 ;8(1):1-6.

14. Safar AA, Ghafoor AO, Dastan D. Chemical composition, antibacterial and antioxidant activities of Tagetes patula L. essential oil raised in Erbil, Iraq. Journal of Reports in Pharmaceutical Sciences. 2020 Jan 1;9(1):59.

15. Hammad M, Sallal AK, Darmani H. Inhibition of Streptococcus mutans adhesion to buccal epithelial cells by an aqueous extract of Thymus vulgaris. International journal of dental hygiene. $2007 ; 5(4): 232-5$.

16. Portillo A, Vila R, Freixa B, Adzet T, Cañigueral S. Antifungal activity of Paraguayan plants used in traditional medicine. Journal of Ethnopharmacology. 2001 1;76(1):93-8.

17. Jain R, Katare N, Kumar V, Samanta AK, Goswami S, Shrotri CK. In vitro antibacterial potential of different extracts of Tagetes erecta and Tagetes patula. J. Nat. Sci. Res. 2012;2: 84-90.

18. Politi FA, Queiroz-Fernandes GM, Rodrigues ER, Freitas JA, Pietro RC. Antifungal, antiradical and cytotoxic activities of extractives obtained from Tagetes patula L.(Asteraceae), A potential acaricide plant species. Microbial pathogenesis. 2016 1;95:15-20.

19. Faizi S, Siddiqi H, Bano S, Naz A, Lubna, Mazhar K, Nasim S, Riaz T, Kamal S, Ahmad A, Khan SA. Antibacterial and antifungal activities of different parts of Tagetes patula.: Preparation of patuletin derivatives. Pharmaceutical Biology. 2008 1;46(5):309-20 . 